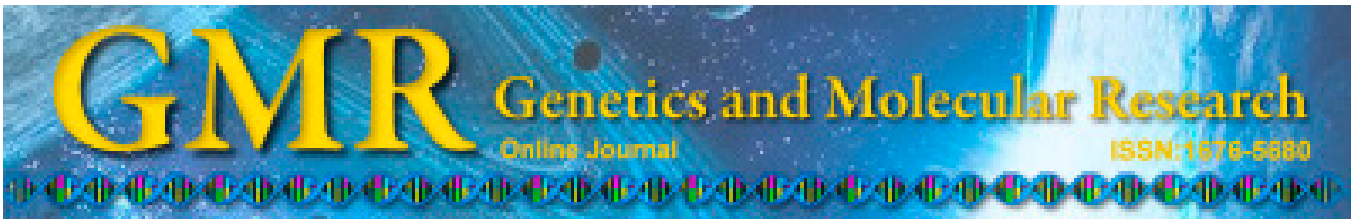

\title{
Adaptability of soybean cultivars in different crop years
}

\author{
I.O. Soares, P.M. Rezende, A.T. Bruzi, E.V. Zambiazzi, A.M. Zuffo, \\ K.B. Silva and R. Gwinner \\ Departamento de Agricultura, Universidade Federal de Lavras, Lavras, MG, \\ Brasil \\ Corresponding author: I.O. Soares \\ E-mail: igoroliveri@yahoo.com.br
}

Genet. Mol. Res. 14 (3): 8995-9003 (2015)

Received January 28, 2015

Accepted May 29, 2015

Published August 7, 2015

DOI http://dx.doi.org/10.4238/2015.August.7.8

\begin{abstract}
Soybean is one of the main sources of foreign exchange credits for Brazil in the agricultural sector. There is increasing interest in growing this leguminous crop, especially in the southern region of Minas Gerais, due to its importance as an alternative for crop rotation with maize. In this respect, the study of the adaptability of new cultivars to the region is indispensable so as to obtain high yields. Thus, the aim of this study was to evaluate the performance of 38 soybean cultivars for growing in the summer season in the municipality of Lavras, MG, Brazil, in the 2010/2011 and 2011/2012 crop years. The experiments were conducted in a randomized block design with 3 replications and the treatments consisted of 38 cultivars. At the time of harvest, the following assessments were made: grain yield $(\mathrm{kg} / \mathrm{ha})$, height of the lowest pod $(\mathrm{cm})$, plant height $(\mathrm{cm})$, and lodging. The data were subjected to individual and combined analysis of variance. The phenotypic mean values were clustered, adopting the Scott and Knott test. For simultaneous selection of multiple traits, the sum of rank index of Mulamba and Mock was adopted. The cultivar TMG 801 RR had the best yield performance; the cultivars Monsoy 8001, MGBR-46
\end{abstract}


(Conquista), and BRSMG 68 (Vencedora) also stood out. Considering simultaneous selection for grain yield, plant height, height of the lowest pod, and lodging, the cultivar TMG $801 \mathrm{RR}$ is recommended for growing in the summer season in the southern region of Minas Gerais.

Key words: Cultivar selection; Genotype $\mathrm{x}$ crop year interaction; Glycine max; Selection index

\section{INTRODUCTION}

Soybean is the main source of foreign exchange credits for Brazil in the agricultural sector. It is estimated that in the 2013/2014 crop year, Brazil will produce approximately 90 million tons of the oilcrop, production $10.8 \%$ greater than the 2012/2013 crop year. The expectation is that Brazil will export 41.5 million tons, maintaining its position as the largest worldwide exporter of soybean (CONAB, 2014).

Due to its economic importance, this crop has been the focus of developing research, especially in the area of breeding, with the attainment of improved cultivars, carriers of alleles able to express broad adaptation and good tolerance to biotic and abiotic factors, representing significant contributions to the productive sector.

The growth and development of soybean and, consequently, grain yield are the result of the interaction between cultivars and factors arising from the growing environment, such as sensitivity to photoperiod and to air temperature, which lead to flowering. The sensitivity of the cultivars in relation to photoperiod and to air temperature, directly related to the beginning of the reproductive period, is the main characteristic for zoning of cultivars (Munsdstock and Thomas, 2005).

As a result of environmental factors in phenotypic expression, a genotype $\mathrm{x}$ environment interaction is expected; i.e., the behavior of the different lines and/or cultivars does not coincide in the environments assessed (Ramalho et al., 2012).

Some studies seeking to confirm better adaptability of available cultivars have been undertaken in various regions of Brazil. Guimarães et al. (2008), in a study carried out in an experimental area of the Universidade Federal de Lavras (Lavras, MG, Brazil), evaluated 40 soybean cultivars and observed that the cultivars with the best results were Vencedora, Conquista, and Monarca.

Conducting an experiment in areas located in two different municipalities (Lavras and Itutinga, MG), Carvalho et al. (2010) evaluated 24 cultivars, finding that the best results were obtained in the following cultivars: Monsoy 8001, Conquista, Vencedora, DM Nobre, Emgopa 315, DM Vitória, Monsoy 6101, Preta, UFV 16, Emgopa 316, Santa Rosa, Aventis 7002, and CAC 1, with grain yields ranging from 2958 to $3575 \mathrm{~kg} / \mathrm{ha}$.

With the aim of evaluating the performance of 17 soybean cultivars in the municipality of Botucatu, SP, in the 2002/2003, 2003/2004, and 2004/2005 crop years, Lemos et al. (2011) observed that most of the materials evaluated attained results greater than $3000 \mathrm{~kg} / \mathrm{ha}$; however, the cultivars IAC 22, BRS 133, and BRS 156 were those that most stood out in the three crop years.

Peluzio et al. (2010) evaluated 17 cultivars in two trials conducted in the municipalities of Palmas, TO and Gurupi, TO. The authors observed a significant effect of the location 
$\mathrm{x}$ cultivar interaction for all the characteristics evaluated, except for the number of days to flowering. The cultivars BRSMG Valiosa, M-SOY 8585 RR, and TMG 106 RR achieved the greatest mean yields.

However, it should be noted that these evaluations considered the cultivar performance in different locations. The crop season effect was not considered. Reports indicate that the genotype-season interactions are quite relevant and should be studied for the selection of cultivars with greater adaptability. In breeding programs, several traits can be analysed simultaneously to identify the desirable cultivar. In this context, a selection index can be applied as a useful tool. There are no reports about the uses of such index aiming to select soybean cultivars with higher performance in the southern region of Minas Gerais State.

In light of the above, the aim of this study was to select soybean cultivars, evaluating them in regard to adaptability to the southern region of Minas Gerais for summer growth over two crop years, considering yield performance and adopting a selection index.

\section{MATERIAL AND METHODS}

The experiments were set up at the Universidade Federal de Lavras (UFLA), located at latitude $21^{\circ} 14$ 'S, longitude $45^{\circ} 00^{\prime} \mathrm{W}$, and altitude of $918 \mathrm{~m}$, in the 2010/2011 and 2011/2012 crop years in a soil classified as Latossolo Vermelho Distroférrico (LVdf; Oxisol). According to the Köppen classification, the climate in the municipality of Lavras is Cwa (Antunes, 1986), rainy temperate, with a dry winter and rainy summer. Average annual rainfall is $1529.7 \mathrm{~mm}$ (INMET, 1992). The rainfall and temperature data over the period of the experiments are shown in Figure 1.

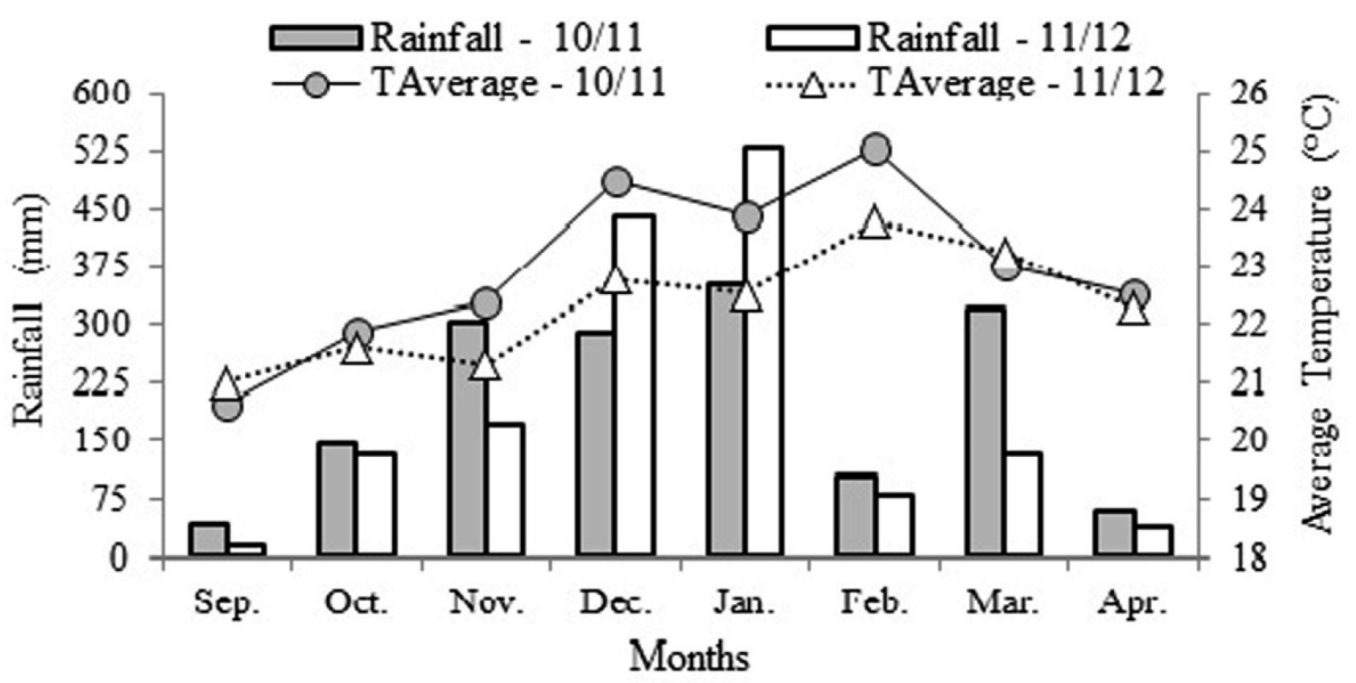

Figure 1. Monthly averages of rainfall and air temperature in Lavras, MG, Brazil, in the 2010/11 and 2011/12 crop years over the time of the trials. Source: Instituto Nacional de Meteorologia (INMET).

A conventional soil tillage system was used, with plowing followed by disking and mechanized opening of planting furrows spaced at $0.50 \mathrm{~m}$. Fertilization followed the recom- 
mendations of the Soil Fertility Commission of the State of Minas Gerais (Ribeiro et al., 1999). Table 1 shows the data in regard to chemical analyses of the soils of the experimental area.

Table 1. Chemical composition of the Latossolo Vermelho Distroférrico típico (Oxisol) soil (0-0.20 m) before setting up the experiments in the 2010/2011 and 2011/2012 crop years (Lavras, MG, Brazil).

\begin{tabular}{|c|c|c|c|c|c|c|c|c|c|}
\hline \multirow{2}{*}{$\begin{array}{l}\text { Crop Years } \\
\mathrm{H}_{2} \mathrm{O}\end{array}$} & \multirow[t]{2}{*}{$\mathrm{pH}$} & $\mathrm{Ca}^{2+}$ & $\mathrm{Mg}^{2+}$ & $\mathrm{Al}^{3+}$ & $\mathrm{H}^{+}+\mathrm{Al}^{3+}$ & SB & CEC & $\mathrm{P}$ & $\mathrm{K}$ \\
\hline & & \multicolumn{6}{|c|}{$\mathrm{cmol}_{\mathrm{c}} / \mathrm{dm}^{3}$} & \multicolumn{2}{|c|}{$\mathrm{mg} / \mathrm{dm}^{3}$} \\
\hline $2010 / 2011$ & 5.20 & 2.10 & 0.30 & 0.20 & 7.90 & 2.70 & 10.30 & 6.00 & 117 \\
\hline \multirow[t]{3}{*}{$2011 / 2012$} & 5.90 & 4.70 & 1.30 & 0.00 & 2.90 & 6.30 & 9.20 & 7.21 & 118 \\
\hline & $\mathrm{Zn}^{2+}$ & $\mathrm{Mn}^{2+}$ & $\mathrm{Cu}^{2+}$ & B & $\mathrm{Fe}^{2+}$ & $\mathrm{S}$ & $\mathrm{OM}$ & $\mathrm{V}$ & \\
\hline & \multicolumn{6}{|c|}{$\mathrm{mg} / \mathrm{dm}^{3}$} & $(\mathrm{dag} / \mathrm{kg})$ & $(\%)$ & \\
\hline $2010 / 2011$ & 2.60 & 13.90 & 3.00 & 0.10 & - & - & 3.40 & 55.9 & \\
\hline $2011 / 2012$ & 5.31 & 13.33 & 0.60 & 0.33 & - & - & 2.61 & 68.51 & \\
\hline
\end{tabular}

Before sowing, the seeds were inoculated with Bradyrhizobium japonicum using the peat-based inoculant Nitral at the proportion of 1,200,000 bacteria per seed.

Seeds were sown manually, and thinning was carried out 25 days after germination, maintaining 15 plants per linear meter. The other crop treatments were performed in a uniform manner in the experimental area according to the procedure presented by Carvalho et al. (2010).

The experimental plots consisted of four 5.0-m length rows, spaced at $0.50 \mathrm{~m}$, using the two center rows as a useful area, with elimination of $0.50 \mathrm{~m}$ at their extremities. A completely randomized block experimental design was adopted, with 3 replications and 38 treatments (Table 2).

At the time of harvest, the following were assessed: height of the lowest pod (distance from the root collar of the plant up to the node of the first pod, in centimeters, of 5 random plants); plant height (distance from the root collar up to the extremity of the main stem, in centimeters, measured in 5 random plants); lodging rate, evaluated according to Bernard et al. (1965) with the following scores: 1 for all upright plants, 2 for some plants leaning or slightly lodged, 3 for all plants moderately leaning or $25-50 \%$ lodged, 4 for all the plants severely leaning or $50-80 \%$ lodged, and 5 for more than $80 \%$ lodged plants; as well as grain yield in $\mathrm{kg} / \mathrm{ha}$ after conversion to $13 \%$ moisture.

Individual analyses, per crop year, for all the traits were made using the statistical model $\mathrm{Y}_{\mathrm{ij}}=\mu+\mathrm{t}_{\mathrm{i}}+\mathrm{r}_{\mathrm{j}}+\mathrm{e}_{\mathrm{ij}}$, where $Y_{i j}$ is observation in reference to treatment $i$ in replication $j ; \mu$ is overall mean; $t_{i}$ is effect of treatment $i ; r_{j}$ is effect of replication $j ; e_{i j}$ is experimental error $\cap \mathrm{N}\left(0, \sigma^{2}\right)$.

Having obtained the mean values per crop year, combined analysis was carried out, considering each experiment as a replication. The experimental error of this analysis corresponds to the cultivar $\mathrm{x}$ crop year interaction. Mean error is obtained by the mean of the mean square error in the individual analyses (Ramalho et al., 2012).

The collected data were subjected to statistical analyses with the assistance of the Sisvar ${ }^{\mathbb{B}}$ software (Ferreira, 2000), using the Scott-Knott test at 5\% for comparison of mean values. 
For selection considering all the traits assessed, the selection index proposed by $\mathrm{Mu}-$ lamba and Mock (1978) was adopted, in which selection is carried out based on classification or ordering of the lines for multiple traits. The principle of the Mulamba and Mock index is transformation of the adjusted phenotypic means of the genotypes for each trait into rankings, according to the interest of the breeder, i.e., in the sense of increasing or decreasing the phenotypic expression. In the present study, the following rankings for yield were adopted: "1" for values above $3000 \mathrm{~kg} / \mathrm{ha}$; "2" for intervals from 2500 to $3000 \mathrm{~kg} / \mathrm{ha}$; and "3" for yields less than $2500 \mathrm{~kg} / \mathrm{ha}$. For plant height, plants of 60 to $120 \mathrm{~cm}$ were considered as ranking " 1 ", and plants less than $60 \mathrm{~cm}$ or greater than $120 \mathrm{~cm}$ received ranking "2". For height of the lowest pod, ranking " 1 " for cultivars with values from 10 to $15 \mathrm{~cm}$, and ranking " 2 " for values less than $10 \mathrm{~cm}$ or greater than $15 \mathrm{~cm}$ was adopted. For cultivars with lodging scores from 1 to 1.9, ranking " 1 " was adopted; ranking " 2 " for scores from 2 to 2.9, and ranking " 3 " for scores as of 3. Based on the rankings of the lines for each characteristic, the sum is established, obtaining the values of the index for each treatment. The cultivars that obtained the lowest total values are selected as those of best overall performance.

Table 2. Cultivars used in the experiments in the 2010/2011 and 2011/2012 crop years (Lavras, MG, Brazil).

\begin{tabular}{|c|c|}
\hline Cultivar & Origin \\
\hline Aventis 7002 & Aventis \\
\hline BRS 136 & Embrapa \\
\hline BRS 137 & Embrapa \\
\hline BRS 255 RR & Embrapa \\
\hline BRS 750 SRR & Embrapa \\
\hline BRS 850 GRR & Embrapa \\
\hline BRS Carla & Embrapa \\
\hline BRS Favorita RR & Embrapa \\
\hline BRS Milena & Embrapa \\
\hline BRSGO 204 (Goiânia) & Embrapa \\
\hline BRSGO Luziânia & Embrapa \\
\hline BRSMG 250 (Nobreza) & Embrapa \\
\hline BRSMG 251 (Robusta) & Embrapa \\
\hline BRSMG 68 (Vencedora & Embrapa \\
\hline BRSMG 760 SRR & Embrapa \\
\hline BRSMG Garantia & Embrapa \\
\hline CAC 1 & Cooperativa Agrícola de Cotia \\
\hline DM Nobre & Agropecuária Dois Marcos \\
\hline Elite & Embrapa \\
\hline Emgopa 315 & Emater-GO \\
\hline Emgopa 316 & Emater-GO \\
\hline MGBR-46 (Conquista) & Embrapa \\
\hline Monarca & Embrapa \\
\hline Monsoy 6101 & Monsanto \\
\hline Monsoy $7211 \mathrm{RR}$ & Monsanto \\
\hline Monsoy $8000 \mathrm{RR}$ & Monsanto \\
\hline Monsoy 8001 & Monsanto \\
\hline Monsoy 8229 & Monsanto \\
\hline NA 7255 RR & Nidera \\
\hline P98Y11 & Pioneer \\
\hline P98Y30 & Pioneer \\
\hline Preta & UFLA \\
\hline Suprema & Embrapa \\
\hline TMG 1179 RR & Tropical Melhoramento e Genética \\
\hline TMG $127 \mathrm{RR}$ & Tropical Melhoramento e Genética \\
\hline TMG 801 RR & Tropical Melhoramento e Genética \\
\hline UFV 16 (Capinópolis) & UFV \\
\hline UFV TN 105 & UFV \\
\hline
\end{tabular}


Experimental precision was evaluated by the accuracy estimate (Resende and Duarte, 2007; Ramalho et al., 2012) using the estimator (Equation 1) shown below:

$$
r=\sqrt[2]{1-\frac{1}{F_{C}}} \times 100
$$

in which, $r$ is the accuracy expressed in percentage; $F_{c}$ is the $\mathrm{F}$ value calculated.

\section{RESULTS AND DISCUSSION}

The summary of combined analysis of variance is shown in Table 3. A significant difference $(\mathrm{P}<0.001)$ was seen for the grain yield and plant height traits. This result shows that there is variability among the cultivars tested for these characteristics.

Table 3. Summary of combined analysis of variance of the grain yield traits (Yield, $\mathrm{kg} / \mathrm{ha}$ ), height of the lowest pod (HLP, cm), plant height (PH, cm), and lodging (LOD) (Lavras, MG, Brazil, 2010/2011 and 2011/2012 crop years).

\begin{tabular}{|c|c|c|c|c|c|}
\hline & \multirow[t]{2}{*}{ d.f. } & \multicolumn{4}{|c|}{ Sum of squares } \\
\hline & & Yield & $\mathrm{PH}$ & HLP & LOD \\
\hline Cultivar (C) & 37 & $187833.02 * *$ & $203.15^{* *}$ & 17.41 & 0.62 \\
\hline Year $(\mathrm{Y})$ & 1 & $494271.59 * *$ & 5.21 & 1.90 & 2.58 \\
\hline $\mathrm{C} \times \mathrm{Y}$ & 37 & $208780.54 * *$ & 52.75 & 13.14 & 0.44 \\
\hline Error & 85 & 63894.12 & 77.11 & 14.51 & 0.68 \\
\hline F calculated (cultivars) & 2.94 & 2.63 & 1.20 & 0.91 & \\
\hline Accuracy $(\%)$ & 81.23 & 78.72 & 40.82 & - & \\
\hline
\end{tabular}

**Significant at $1 \%$ probability by the F-test.

In the average of the crop years, a significant difference was not detected for lodging and height of the lowest pod. This was expected - since the treatments assessed are commercial cultivars that are already recommended, it is expected that these traits remain within the required commercial standard.

The cultivar $\mathrm{x}$ crop year interaction was significant for the grain yield trait, showing that the behavior of the cultivars did not coincide in the different years (Table 3 ). The genotype $\mathrm{x}$ environment interaction is frequently reported in the literature for different crops (Ramalho et al., 2012). In the soybean crop, this is also an important fact.

The magnitude of the interaction may be observed by the ratio between the sum of squares of the interaction and the total sum of squares. Notice that in the present study, interaction explained $37.5 \%$ of the total variation. This fact shows the importance of testing cultivars in different crop years (Table 3).

According to Allard and Bradshaw (1964), there are foreseeable and unforeseeable environmental factors. In this context, it may be inferred that there is a great variation from one crop year to another in regard to unforeseeable factors because normally the water regime and the occurrence of pests and diseases are different and have a direct effect on expression of the production potential of the cultivar. 
Accuracy estimates reflect the precision in which experiments were conducted and also the existence of variability. According to Ramalho et al. (2012), accuracy estimates above $70 \%$ are considered to be of high magnitude. In this study, that level was observed for the grain yield and plant height traits (Table 3 ).

The plant height characteristic is directly related to yield, the degree of lodging, and efficiency in mechanized harvest, and it is thus of fundamental importance that this trait be assessed in the selection of cultivars with good adaptability to a new region because it undergoes changes from environmental factors. In the present study, a satisfactory height was observed for mechanized harvest in all the cultivars studied, ranging from $69 \mathrm{~cm}$ in BRS $255 \mathrm{RR}$ to $110.5 \mathrm{~cm}$ in the Suprema cultivar. Values from 60 to $120 \mathrm{~cm}$ are considered ideal (Carvalho, 2009) (Table 4).

Table 4. Phenotypic mean values of the traits of grain yield (Yield, $\mathrm{kg} / \mathrm{ha}$ ), plant height $(\mathrm{PH}, \mathrm{cm})$, height of the lowest pod (HLP, cm), and lodging index obtained in the cultivar selection trials (UFLA, Lavras, MG, 2010/2011 and 2011/2012 crop years).

\begin{tabular}{|c|c|c|c|c|}
\hline Cultivars & Yield (kg/ha) & $\operatorname{HLP}(\mathrm{cm})$ & PH (cm) & Lodging \\
\hline TMG 801 RR & $3772.00^{\mathrm{a}}$ & $22.50^{\mathrm{b}}$ & $93.00^{b}$ & $2.00^{\mathrm{c}}$ \\
\hline Monsoy 8001 & $3446.00^{\mathrm{b}}$ & $20.00^{\mathrm{b}}$ & $87.00^{\mathrm{b}}$ & $2.00^{\mathrm{c}}$ \\
\hline MGBR-46 (Conquista) & $3370.50^{\mathrm{b}}$ & $25.00^{\mathrm{a}}$ & $88.00^{\mathrm{b}}$ & $1.50^{\mathrm{b}}$ \\
\hline BRSMG 68 (Vencedora) & $3293.00^{\mathrm{b}}$ & $23.00^{\mathrm{a}}$ & $94.00^{\mathrm{b}}$ & $2.50^{\mathrm{c}}$ \\
\hline UFV 16 (Capinópolis) & $3125.00^{\mathrm{c}}$ & $21.00^{\mathrm{b}}$ & $100.00^{\mathrm{b}}$ & $2.00^{\mathrm{c}}$ \\
\hline P98Y11 & $3106.50^{c}$ & $24.00^{\mathrm{a}}$ & $87.50^{\mathrm{b}}$ & $1.50^{\mathrm{b}}$ \\
\hline TMG 1179 RR & $3106.00^{c}$ & $18.50^{\mathrm{b}}$ & $77.00^{\mathrm{c}}$ & $1.50^{\mathrm{b}}$ \\
\hline Aventis 7002 & $3035.00^{\mathrm{c}}$ & $24.50^{\mathrm{a}}$ & $89.00^{\mathrm{b}}$ & $1.50^{\mathrm{b}}$ \\
\hline Elite & $2977.50^{c}$ & $22.50^{\mathrm{b}}$ & $105.50^{\mathrm{a}}$ & $3.00^{\mathrm{c}}$ \\
\hline DM Nobre & $2945.50^{c}$ & $25.00^{\mathrm{a}}$ & $105.50^{\mathrm{a}}$ & $3.00^{\mathrm{c}}$ \\
\hline CAC 1 & $2937.50^{c}$ & $28.00^{\mathrm{a}}$ & $93.50^{b}$ & $2.50^{\mathrm{c}}$ \\
\hline BRS 136 & $2931.50^{c}$ & $23.50^{\mathrm{a}}$ & $96.50^{\mathrm{b}}$ & $2.00^{\mathrm{c}}$ \\
\hline BRSMG 760 SRR & $2902.50^{\mathrm{c}}$ & $22.00^{\mathrm{b}}$ & $102.50^{\mathrm{a}}$ & $2.00^{\mathrm{c}}$ \\
\hline Emgopa 316 & $2861.00^{\mathrm{c}}$ & $26.00^{\mathrm{a}}$ & $106.50^{\mathrm{a}}$ & $2.50^{\mathrm{c}}$ \\
\hline BRS Milena & $2860.00^{c}$ & $22.00^{\mathrm{b}}$ & $85.50^{c}$ & $2.00^{\mathrm{c}}$ \\
\hline BRSMG 251 (Robusta) & $2855.50^{\mathrm{c}}$ & $21.00^{\mathrm{b}}$ & $93.00^{\mathrm{b}}$ & $1.50^{\mathrm{b}}$ \\
\hline Monsoy 8000 RR & $2834.00^{\mathrm{c}}$ & $20.50^{\mathrm{b}}$ & $88.00^{\mathrm{b}}$ & $1.00^{\mathrm{a}}$ \\
\hline BRS Favorita RR & $2789.00^{\mathrm{c}}$ & $25.00^{\mathrm{a}}$ & $83.00^{c}$ & $1.50^{\mathrm{b}}$ \\
\hline BRS Carla & $2757.50^{\mathrm{d}}$ & $22.50^{\mathrm{b}}$ & $101.50^{\mathrm{a}}$ & $3.00^{c}$ \\
\hline BRS 750 SRR & $2741.50^{\mathrm{d}}$ & $23.50^{\mathrm{a}}$ & $82.50^{c}$ & $1.50^{\mathrm{b}}$ \\
\hline BRSGO 204 (Goiânia) & $2712.50^{\mathrm{d}}$ & $24.50^{\mathrm{a}}$ & $95.50^{\mathrm{b}}$ & $1.50^{\mathrm{b}}$ \\
\hline Emgopa 315 & $2705.50^{\mathrm{d}}$ & $21.00^{\mathrm{b}}$ & $81.00^{c}$ & $2.00^{\mathrm{c}}$ \\
\hline BRSMG Garantia & $2680.50^{\mathrm{d}}$ & $31.00^{\mathrm{a}}$ & $105.00^{\mathrm{a}}$ & $2.00^{\mathrm{c}}$ \\
\hline Monsoy 6101 & $2680.00^{\mathrm{d}}$ & $24.00^{\mathrm{a}}$ & $94.00^{\mathrm{b}}$ & $2.50^{\mathrm{c}}$ \\
\hline BRS 850 GRR & $2672.00^{\mathrm{d}}$ & $17.50^{\mathrm{b}}$ & $82.50^{c}$ & $1.50^{\mathrm{b}}$ \\
\hline NA 7255 RR & $2657.50^{\mathrm{d}}$ & $18.00^{\mathrm{b}}$ & $79.00^{c}$ & $1.00^{\mathrm{a}}$ \\
\hline Suprema & $2643.50^{d}$ & $24.50^{\mathrm{a}}$ & $110.50^{\mathrm{a}}$ & $2.50^{\mathrm{c}}$ \\
\hline Monarca & $2642.50^{\mathrm{d}}$ & $20.00^{\mathrm{b}}$ & $104.00^{\mathrm{a}}$ & $2.50^{\mathrm{c}}$ \\
\hline TMG 127 RR & $2602.50^{d}$ & $20.00^{\mathrm{b}}$ & $96.50^{\mathrm{b}}$ & $2.00^{\mathrm{c}}$ \\
\hline Preta & $2583.50^{\mathrm{d}}$ & $23.50^{\mathrm{a}}$ & $88.50^{\mathrm{b}}$ & $1.50^{\mathrm{b}}$ \\
\hline BRSMG 250 (Nobreza) & $2555.50^{\mathrm{d}}$ & $22.00^{\mathrm{b}}$ & $83.00^{c}$ & $2.50^{\mathrm{c}}$ \\
\hline Monsoy 8229 & $2546.00^{\mathrm{d}}$ & $21.50^{\mathrm{b}}$ & $90.50^{\mathrm{b}}$ & $2.50^{\mathrm{c}}$ \\
\hline BRS 137 & $2540.00^{\mathrm{d}}$ & $20.00^{\mathrm{b}}$ & $70.00^{\mathrm{d}}$ & $1.50^{\mathrm{b}}$ \\
\hline BRS 255 RR & $2533.00^{\mathrm{d}}$ & $19.00^{\mathrm{b}}$ & $69.00^{\mathrm{d}}$ & $1.50^{\mathrm{b}}$ \\
\hline BRSGO Luiziânia & $2506.50^{\mathrm{d}}$ & $26.50^{\mathrm{a}}$ & $96.00^{b}$ & $2.50^{\mathrm{c}}$ \\
\hline UFV TN 105 & $2451.50^{\mathrm{d}}$ & $16.50^{\mathrm{b}}$ & $85.50^{c}$ & $1.00^{\mathrm{a}}$ \\
\hline Monsoy 7211 RR & $2431.50^{\mathrm{d}}$ & $21.0^{\mathrm{b}}$ & $98.00^{\mathrm{b}}$ & $1.50^{\mathrm{b}}$ \\
\hline P98Y30 & $2282.50^{\mathrm{d}}$ & $20.50^{\mathrm{b}}$ & $81.50^{c}$ & $2.00^{\mathrm{c}}$ \\
\hline Standard error & 103.19 & 1.55 & 3.58 & 0.33 \\
\hline
\end{tabular}

* Mean values followed by the same letters belong to the same group by the Scott and Knott test at 5\% probability. 
Just as for plant height, height of the first pod has a direct effect on mechanized harvest. If the height of the first pod is below $10 \mathrm{~cm}$, there may be losses in the operation because the combine has to operate very near the soil. According to Marcos Filho (1986), satisfactory height is around $15 \mathrm{~cm}$. Among the cultivars assessed, height of the first pod ranged from 16.5 $\mathrm{cm}$ in the cultivar UFV TN 105 to $31 \mathrm{~cm}$ in the cultivar BRSMG Garantia (Table 4).

Highly affected by plant height, lodging plays an important role in cultivar selection since lodged plants make mechanized harvest unviable. In the present study, scores from 1.00 to 3.00 were observed; the lowest values were observed in the cultivars UFV TN 105, NA 7255 RR, and Monsoy 8000 RR. However, it should be emphasized that, in spite of the differences observed, significance for the trait was not detected (Table 4).

The cultivars, as was expected, showed wide variation in yield, ranging from 2282.5 to $3772 \mathrm{~kg} / \mathrm{ha}$, which shows the importance of this study since the goal is to identify those with greatest adaptability. It was observed that for the southern region of Minas Gerais, in the municipality of Lavras, the cultivar that showed the highest yield was TMG 801 (3772 kg/ha). Other cultivars that showed good performance were Monsoy 8001 (3446 kg/ha), MGBR-46 (Conquista) (3370.5 kg/ha), and BRSMG 68 (Vencedora) $(3293 \mathrm{~kg} / \mathrm{ha})$, which do not differ among themselves by the Scott and Knott test (Table 4). However, it should be noted that the cultivars of greatest performance showed yield greater than the national average of $3106 \mathrm{~kg} /$ ha, obtained in the 2010/2011 crop year.

In plant breeding, the breeder normally assesses various traits and, in this context, simultaneous selection is necessary for these characteristics assessed. In this regard, the adoption of selection indices constitutes a good strategy. There are various alternatives available in the literature; however, the Mulamba and Mock (1978) index is a worthwhile and easily used alternative. By this method, classification of the treatments is obtained for the different traits and a ranking is attributed. After that, the sum is calculated. The cultivar with the lowest total value is selected as the best, i.e., it showed the best performance in most of the traits assessed. In the present study, this strategy was used and the results are shown in Table 5. Notice that, adopting this tool, the cultivar TMG 801 RR may be selected.

Table 5. Result of the rank sum test considering the traits of grain yield, plant height, height of the lowest pod, and lodging (Lavras, MG, Brazil, 2010/2011 and 2011/2012 crop year).

\begin{tabular}{lclc}
\hline Cultivar & Rank sum & Cultivar & Rank sum \\
\hline TMG 801 RR & 6 & BRSMG 760 SRR & 8 \\
MGBR-46 (Conquista) & 7 & BRS Milena & 8 \\
P98Y11 & 7 & Emgopa 315 & 8 \\
TMG 1179 RR & 7 & BRSMG Garantia & 8 \\
Aventis 7002 & 7 & TMG 127 RR & 8 \\
Monsoy 8001 & 7 & UFV TN 105 & 8 \\
UFV 16 (Capinópolis) & 7 & CAC 1 & 9 \\
Monsoy 8000 RR & 7 & Emgopa 316 & 9 \\
NA 7255 RR & 7 & Monsoy 6101 & 9 \\
BRSMG 68 (Vencedora) & 8 & Suprema & 9 \\
BRSMG 251 (Robusta) & 8 & Monarca & 9 \\
BRS Favorita RR & 8 & BRSMG 250 (Nobreza) & 9 \\
BRS 750 SRR & 8 & Monsoy 8229 & 9 \\
BRSGO 204 (Goiânia) & 8 & BRSGO Luiziânia & 9 \\
BRS 850 GRR & 8 & Monsoy 7211 RR & 9 \\
Preta & 8 & Elite & 9 \\
BRS 137 & 8 & DM Nobre & 9 \\
BRS 255 RR & 8 & BRS Carla & 9 \\
BRS 136 & 8 & P98Y30 & 9 \\
\hline
\end{tabular}


The cultivar TMG 801 RR shows degree of maturity of 8.2 and a determined growth habit. It is resistant to stem canker, soybean rust, and frogeye leaf spot; however, it is susceptible to target leaf spot.

The results of this study allow us to identify cultivars with improved agronomic performance for the region under study. Despite this region being known by coffee, maize and milk production, currently, it is considered to have an expressive potential for soybean production.

During the last 3 years, the soybean planted area have increased $50.78 \%$ in the region, totaling 40,498 hectares cultivated with this crop (IBGE, 2014). In this context, the present study indicates cultivars that can be used in the region.

\section{CONCLUSIONS}

The cultivar TMG 801 RR showed the best yield performance; in addition, the cultivars Monsoy 8001, MGBR-46 (Conquista), and BRSMG 68 (Vencedora) stood out.

Considering simultaneous selection for grain yield, plant height, height of the first pod, and lodging, the cultivar TMG $801 \mathrm{RR}$ is recommended for growing in the summer in the southern region of Minas Gerais.

\section{REFERENCES}

Allard RW and Bradshaw AD (1964). Implications of genotype-environmental interactions in applied plant breeding. Crop Scienc. 4: 503-508.

Antunes FZ (1986). Caracterização climática do Estado de Minas Gerais. Inf. Agropec. 138: 9-13.

Bernard RL, Chamberlain DW and Lawrence RD (1965). Results of the cooperative uniform soybean tests. USDA, Washington.

Carvalho ER, Rezende PM de, Ogoshi FGA, Botrel EP, et al. (2010). Desempenho de cultivares de soja em cultivo de verão no Sul de Minas Gerais. Cienc. Agrotecnol. 34: 892-899.

CONAB (2014). Companhia Nacional de Abastecimento, Brasília, 2013. Available at [http://www.conab.gov.br]. Accessed March 28, 2013.

Ferreira DF (2000). Sistema de análises de variância para dados balanceados. Universidade Federal de Lavras, Lavras.

Guimarães FS, Rezende PM, Castro EM, Carvalho EA, et al. (2008). Cultivares de soja para cultivo de verão na Região de Lavras - MG. Cienc. Agrotecnol. 32: 1099-1106.

INMET (Departamento Nacional de Meteorologia do Ministério da Agricultura e Reforma Agrária) (1992). Normais climatológicas: 1961-1990. INMET, Brasília.

Lemos LB, Farinelli R, Cavariani C and Zapparoli RA (2011). Desempenho agronômico e produtivo de cultivares de soja em diferentes safras. Cientifica 39: 44-51.

Marcos Filho J (1986). Produção de sementes de soja. Fundação Cargill, Campinas.

Mulamba NN and Mock JJ (1978). Improvement of yield potential of the Eto Blanco maize (Zea mays L.) population by breeding for plant traits. Egyptian J. Genet Cytol. 7: 40-51.

Mundstock CM and Thomas AL (2005). Soja: Fatores que afetam o crescimento e o rendimento dos grãos. Departamento de Plantas de Lavoura da Universidade do Rio Grande do Sul, Porto Alegre.

Peluzio JM, Melo VF, Afferri FS and Pimenta RS (2010). Adaptabilidade e estabilidade de cultivares de soja, sob condições de várzea irrigada, no Tocantins. Rev. Cienc. Agronômica 41: 427-434.

Ramalho MAP, Santos JB, Abreu AFB and Nunes JAR (2012). Aplicações da genética quantitativa no melhoramento de plantas autógamas. 1st edn. Universidade Federal de Lavras, Lavras.

Resende MDV and Duarte JB (2007). Precisão e controle de qualidade em experimentos de avaliação de cultivares. Pesq. Agropec. Tropical 37: 182-194.

Ribeiro AC, Guimarães PTG and Alvares VH (1999). Recomendações para o uso de corretivos e fertilizantes em Minas Gerais: $5^{\text {a }}$ Aproximação, Viçosa. 